\title{
Corporate Social Responsibilities and Cost of Capital
}

\author{
Fenny Marietza ${ }^{1}$, Intan Kurnida Julianti ${ }^{2}$, Nila Aprila ${ }^{3}$, Madani Hatta ${ }^{4}$, Baihaqi ${ }^{5}$ \\ Faculty of Economics and Business, University of Bengkulu ${ }^{1,2,3,4,5}$ \\ \{mari3tza@gmail.com¹, intankurnidajulianti@gmail.com², madani.unib2006@gmail.com³, \\ nilaaprila@gmail.com ${ }^{4}$,baihaqi.netty@gmail.com $\left.{ }^{5}\right\}$
}

\begin{abstract}
This research aims to provide empirical evidence the effect of corporate social responsibility disclosure on the cost of capital on BUMN companies listed on the Indonesia Stock Exchange with an observation period from 2013-2017. The measurement of corporate social responsibility disclosure using Indeks Global Reporting Initiative G4 (GRI-G4). The cost of capital is divided into 2 namely the cost of equity using the Easton 2004 Model and the cost of debt using the Francis and Periera Model 2005. The sample selections method is the purposive sampling method which totals 13 samples with 65 observations. The results showed that the disclosure of corporate social responsibility has an influence on the cost of equity. Meanwhile, the disclosure of corporate social responsibility has no effect on the cost of debt.
\end{abstract}

Keywords: Corporate Social Responsibility Disclosure; The Cost of Capital; The Cost of Equity; The Cost of Debt

\section{Introduction}

Corporate Social Responsibility disclosure is very important implemented by a company, this can be proven by the existence of Global Compact, Global Reporting Initiatives (GRI), and ISO 26000. Corporate Social Responsibility is not only the responsibility of the government but also the responsibility of the private sector to participate in the development of the community. In Indonesia, corporate social responsibility disclosure has become one of the must-do things in a company's business, where corporate social responsibility disclosure practices in Indonesia have been changed from voluntary to mandatory and increasingly important, this is because the existence of companies around the community can create positive and negative aspects. At a time when the company is growing, social inequality and environmental damage can occur (Lako, 2011).

The Government of Indonesia has listed various regulations governing entities in carrying out corporate social responsibility, this is an effort by the government to protect the environment and ecosystem in order to be well maintained. The regulation is contained in Article 74 of Law Number 40 of 2007 concerning Limited Liability Company relating to the implementation of sustainable finance and in article 66 paragraph 6 of the Social and Environmental Responsibility Implementation Report shall be included in the annual report of public entities. Furthermore, the Financial Accounting Standards Statement (PSAK) Number 1 on the presentation of financial statements in (revised 2009) paragraph 12 also advises making disclosures on social responsibility. 
The regulation stipulated by the government shows that the government is one of the parties concerned with the company to demand that the company be involved in the management of the community and the environment. The Company has an obligation to perform a social liability to stakeholders towards the company. In the theory of stakeholders, stakeholders in business practices, company owners, consumers, employees and trade unions, suppliers, governments, competitors, consumer advocacy, environmental activists, special interest groups, and media (Freeman, 1984). According to Elkington (1997) mentions an understanding of 3P (profit, people, planet), which is the purpose of the business practice to profit, prosper people, and ensure the sustainability of the life of the company (planet). There is a detailed disclosure of corporate social responsibility, so the company is expected to balance this understanding of $3 \mathrm{P}$ and provide additional information for stakeholders in assessing the company's performance. Furthermore, publishing a corporate social responsibility disclosure report will indicate that the company believes in the performance of corporate social responsibility in the company which can further increase the value and image of the company towards stakeholders for the better (Dhaliwal, Li, Tsang, dan Yang, 2011). The cost of capital consists of the cost of debt and the cost of equity. Equity capital costs are the level of return that investors expect when they invest in the company, a form of return that investors request in the form of dividends or capital gains (Ross, Westerfield, dan Jaffe, 1998). While the cost of debt is the yield rate required by the creditor when conducting funding in a company. The debt fee charged to the company is the interest expense that the company must pay to the creditor when making the loan (Fabozzi, 2007). Some research that has been done such as research from Trisnawati and Setiawati (2016) conducted research on the effect of corporate social responsibility disclosure on the cost of equity capital. The results showed that corporate social responsibility disclosure had a significant positive effect on the cost of equity capital. While Bhuiyan and Nguyen's research (2019) conducted research into the influence of corporate social responsibility disclosure on the cost of debt and cost of equity capital. The results showed that corporate social responsibility disclosure had a significant negative effect on the cost of equity capital. And the results of corporate social responsibility disclosure research have a negative and significant effect on the cost of debt.

In the research conducted by Ariyani and Nugrahanti (2013) conducted research on the effect of corporate social responsibility disclosure on the cost of equity. The results showed that corporate social responsibility disclosure had no significant effect on the cost of equity. While Arianti research (2019) conducted research on the influence of corporate social responsibility disclosure, tax avoidance and corporate governance on debt costs. The results showed that corporate social responsibility disclosure had no significant effect on the cost of debt.

This research refers to previous research conducted in Australia by Bhuiyan and Nguyen (2019) with the title of research namely the impact of CSR on the cost of debt and cost of equity Australian evidence. The difference between this study and the referenced research lies in the proxies used in the dependent variables the cost of equity, samples, and periods used. In this study, using dependent variables Cost Of Capital, where Cost Of Capital in this study there are two variables studied namely Cost Of Debt and Cost Of Equity and independent variable Disclosure of Corporate Social Responsibility using a sample of BUMN companies listed on the Indonesia Stock Exchange (IDX) period 2013-2017. Another difference in this study is that the proxy used for one of the dependent variables is the cost of equity using a proxy from Easton 2004 namely the Price-earning Growth Model (PEG).

The formulation of the problem in this study is whether corporate social responsibility disclosure negatively affects the cost of equity, whether corporate social responsibility 
disclosure negatively affects the cost of debt. The purpose of this research is to provide empirical evidence that corporate social responsibility disclosure affects the cost of equity and the cost of debt.

\section{Theoretical Framework and Hypothetical Development}

\subsection{Stakeholder Theory}

According to (Freeman 1984:46) defining stakeholders within the company is any group or individual who can affect or is affected by the achievement of the organization's objecetives. The company is able to grow and develop well then become a big needed support from stakeholders. Stakeholders need a variety of information related to the company's activities used in decision making. Therefore, the company will strive to provide a variety of information that is owned to attract and seek support from stakeholders including nonfinancial information provided by the company.

Corporate social responsibility disclosure can be the company's strategy to meet the interests of stakeholders of non-financial information related to the social and environmental impacts arising from the company's activities (Lako, 2011). The better and broader disclosure of corporate social responsibility conducted by the company will make stakeholders provide support to the company for all its activities aimed at improving the company's performance as well as financial performance and can achieve the expected profit. Thus, if the financial performance improves then the creditor will provide attractive loan terms to the company to conduct the company's operational activities, as well as investors are interested in investing in the company so as to improve the company's performance as well as the value of the company in the eyes of stakeholders indicated by the increasing demand for corporate securities and can lower the risk of the company (Botosan, 1997). The lower the risk of the company, the lower the cost of capital. The company's capital costs here are the cost of equity and the cost of debt. Where the lower the risk of the company then the rate of return charged by the creditor will be low and the rate of return expected by investors will be low, which will have an impact on the decrease in the cost of debt and the cost of equity of the company.

\subsection{Corporate Social Responsibility Disclosure}

According to Lawrence and Weber (2008) Corporate Social Responsibility means that a corporation must take responsibility for its actions that impact society, communities and the environment. If a company's actions harm society, communities and the environment then the company must set aside its profits to prevent such negative impacts. Conversely, if the company's actions have a positive impact on the community, community and environment, the company will have a positive social impact. Elkington (1997) developed the concept of triple bottom line in terms of economic prosperity, environmental quality and social justice. Elkington gives the view that companies that want to be sustainable, should pay attention to "3P". In addition to pursuing profit the company should also pay attention and be involved in fulfilling the welfare of the people and contribute actively in maintaining the sustainability of the environment (planet). The ideal relationship between profit, people, environment (planet) is balanced, can not be concerned with one element only. This 3P concept according to Elkington (1997) can guarantee the continuity of the company's business. Because if a company is just chasing profit, it can be a broken environment and neglected society becomes 
an obstacle to its business continuity. If there is a disturbance from the community then the loss is his own business.

\subsection{The Cost of Capital}

Cost of Capital or capital costs according to Ross, Westerfield, and Jaffe, (1998) the company in obtaining capital to finance its operations through two ways, namely debt and equity. Cost of capital consists of:

\subsection{The Cost of Equity}

The cost of equity here refers only to the rate of return that is the investor's right to invest in a particular company (Ross, Westerfield, and Jaffe, 1998). According to Botosan (1997) the cost of equity is influenced by the level of disclosure and risk. The level of disclosure further increases the liquidity of market shares thus reducing the cost of equity either through the reduction of transaction costs or the increasing demand for corporate securities. Meanwhile, the risk to the company is low then the level of return expected by investors will be low, so the cost of equity of the company is low. This cost of equity is related to the investment risk of the company's shares. One of the risks to be aware of is the risk of information related to the disclosure of information made by the company.

\subsection{The Cost of Debt}

According to Fabozzi (2007) The cost of debt is defined as the yield required by the creditor when funding a company. The cost of debt charged to the company is the interest expense that must be paid by the company to the creditor when making the loan. The cost of debt tends to be easily determined based on observations on the prevailing interest rate in the market.

\section{Research Hypothesis}

\subsection{Hypothetical Development}

\section{a) Corporate Social Responsibility Disclosure and The Cost Of Equity}

Based on the theory of stakeholders, corporate is not an entity that only operates for its own benefit, but must benefit the stakeholders, by making corporate social responsibility disclosures then the stakeholders will also provide support for all corporate activities. Support from stakeholders will make the company last longer and continue so that the more social information that the company discloses that is expected to increase the value of the company indicated by the increased demand for securities and the increase in the share price owned by a company so that this can make the risk of the company decrease, the lower the risk of the company will have an impact on the reduction of the cost of equity of the company (Rinobel and Laksito , 2015).

The research conducted by Bhuiyan and Nguyen (2019) conducted research on the effect of corporate social responsibility disclosure on the cost of debt and cost of equity capital. The results showed that corporate social responsibility disclosure had a significant negative effect 
on the cost of equity capital. The statement is in line with research conducted by Rinobel and Laksito (2015) showing a negative relationship between corporate social responsibility disclosure and the cost of equity capital, so the hypotheses that can be developed are:

H1 : Corporate Social Responsibility Disclosure Negatively Affects The Cost Of Equity.

\section{b) Corporate Social Responsibility Disclosure and the Cost of Debt}

The stakeholder theory put forward by (Freeman 1984) states that the more and stronger the position of stakeholders, the greater the tendency of companies to adapt themselves to the wishes of their stakeholders. Thus, this can support the sustainability of the company, so that the longer the company operates it can make the company make extensive disclosure of activity information. Therefore, the broader the disclosure of corporate social information, the more transparent the company will be, which will have an impact on the decision of creditors so that they can better know, assess, and trust the company. So they will be interested in providing loans with low interest expense, and will bring the impact of the decreased cost of corporate debt.

Research from Goss and Roberts (2011) proves that there is a significant negative relationship between corporate social responsibility disclosure and the cost of debt. The statement is in line with research conducted by Bhuiyan and Nguyen (2019) which shows that corporate social responsibility disclosure has a negative and significant effect. So that the hypotheses that can be developed are:

H2 : Corporate Social Responsibility Disclosure Negatively Affects The Cost Of Debt.

\subsection{Frame of Mind}

Based on the hypothesis that has been formulated before, the frame of mind will be described as follows:

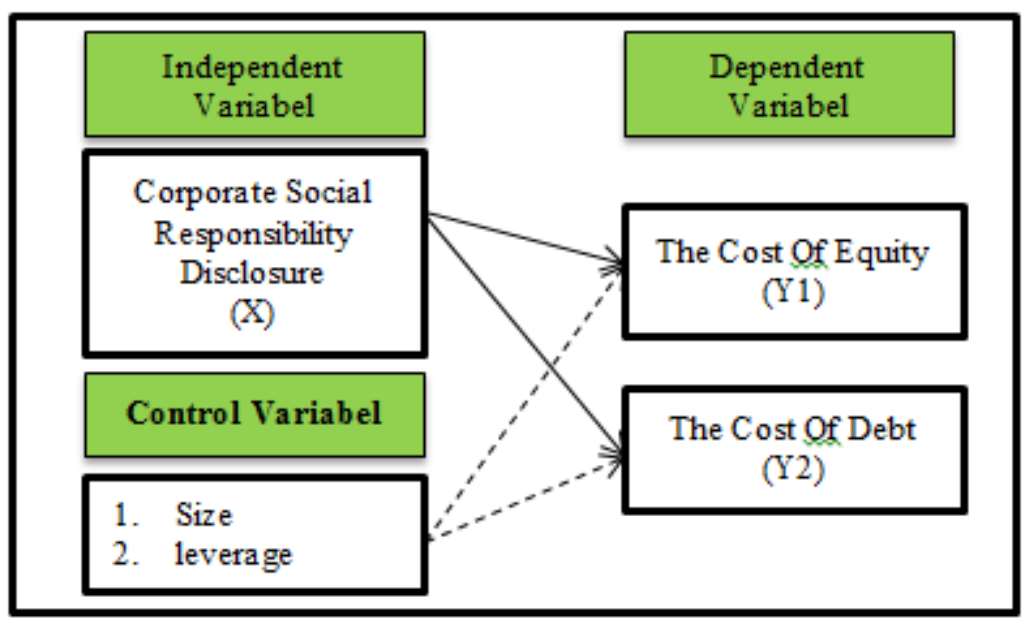

Fig. 1. Frame of Mind 


\section{Research Methods}

\subsection{Corporate Social Responsibility Disclosure}

Corporate social responsibility disclosure is measured by the content analysis of The Corporate Social Responsibility Disclosure Index (CSRDI) index, based on the GRI (Global Reporting Initiatives)-G4 indicator consisting of 91 disclosure items. Gri indicators are chosen because they are international rules that have been recognized by companies in the world. The approach to calculating CSRDI is basically a CSR item given a score of 1 if disclosed and a score of 0 if not disclosed. Furthermore the score of each disclosure item is summed up to obtain the overall score for each company. GRI-G4 is designed to be universally applicable to all companies large and small around the world. Measurements made based on each company's disclosure index are calculated through the division between the number of items disclosed by the company and the number of Corporate Social Responsibility disclosure items. The calculation formula of Corporate Social Responsibility Disclosure Index (CSRDI) is as follows:

Table 1. GRI-G4 Guideline Index

\begin{tabular}{cll}
\multicolumn{3}{c}{ Table 1. GRI-G4 Guideline Index } \\
\hline No & \multicolumn{1}{c}{ Category } & Item Disclosure \\
\hline 1 & Human Rights & 12 Disclosures \\
2 & Society & 11 Disclosures \\
3 & Labor Practices and Decent work & 16 Disclosures \\
4 & Product Responsibility & 9 Disclosures \\
5 & Economy & 9 Disclosures \\
6 & Enviromental & 34 Disclosures \\
& Number of Disclosures & 91 Disclosures \\
\hline \multicolumn{2}{c}{ Source: www.globalreporting.org }
\end{tabular}

The calculation formula for Corporate Social Responsibility Disclosure Index (CSRDI) is as follows: 1

$\operatorname{CSRDI}_{i}=\frac{2 X_{i j}}{n_{i}} \times 100 \%$

Where $C S R D I_{j}$ is the corporate Corporate Social Responsibility Disclosure Index j. $\Sigma X_{i j}$ is the number of Corporate Social Responsibility disclosure items disclosed by the company $\mathrm{j}$. 1 if the item is disclosed and 0 if the item is not disclosed. $n_{i}$ is the number of Corporate Social Responsibility disclosure items.

\subsection{The Cost of Equity}

The cost of equity measurement model is using easton model (2004) price-earning growth model (PEG) with the theory that if the estimation of future accounting profit is the same as the profit from the economy. This model is more effective at knowing the rate of return expected by investors, as it can describe income and revenue growth and it shows how this model can be used to get an estimated expected return on equity capital. If the PEG ratio is high then it indicates that investors expect a low rate of return. This model is based on the Ohlson and Juettner Nauroth models (2000). 


$$
R_{P E Q}=\sqrt{\frac{E P Y_{f+z^{-}}-E P Y_{s+3}}{P_{i}}}
$$

Where $R_{\mathrm{PEC}}$ is the cost of equity, EPS $S_{i+z}$ is earnings per share two years after the publication date of the annual report and EPS $S_{t+1}$ is earnings per share one year after the publication date of the annual report, while $P_{0}$ adalah is the share price at the time of publication of the annual report.

\subsection{The Cost of Debt}

This measurement model for the cost of debt is adapted from Francis and Pereira's research (2005) in which the cost of debt is calculated by dividing the current year's interest expense with the average interest or interest-bearing debt. The higher the cost of debt then indicates that the creditor asks for a high rate of return to the company.

COD $=\frac{\text { laterat expanse on debt }}{\text { Average interest bearing debt }}$

Where COD is the cost of debt. Interest expense on debt the interest expense paid. Averagage interest bearing debt is the average interest or interest-bearing debt.

\subsection{Size}

The Size of the Company is an overview of shareholder welfare. The higher the size of the company, the more prosperous the owner can be. According to Mardiyah (2002) found the size of the company (proxyed by the company's total assets) had a positive relationship with the level of disclosure. The size of the company is assessed based on the natural logarithm of the company's total assets at the end of the period in the financial statements. So that the size of the company can be calculated with the following formula:

Size $=\operatorname{Ln}($ Total Asset $)$

\subsection{Leverage}

Leverage is the company's ability to pay off its long-term liabilities. The higher the leverage of the company, the better the transfer of prosperity from creditors to the company's shareholders. Therefore, highly leveraged companies have higher obligations to meet the information needs of long-term creditors. Leverage in this study is calculated using debt to asset ratio, this ratio is a tool to measure how much the company depends on the creditor in financing the company's assets. Debt to Asset Ratio is calculated using the formula from (Kasmir, 2009) :

D.AR $=\frac{\text { Total Liabilitias }}{\text { Total Asset }} \times 100 \%$

\section{a) Population and Samples}

In this study using a sampling technique namely purposive sampling, the population used in this study is BUMN companies listed on the Indonesia Stock Exchange (IDX) period 2013- 
2017. The sample criteria of the company studied are as follows:

1. BUMN companies that publish annual reports and ongoing reports for the period 20132017.

2. BUMN companies that issue financial statements for the period 2018-2019 that will be used as estimates for earnings per share (EPS) in 2017.

3. Companies that use only in rupiah currency because the expected data is homogeneous.

4. Companies that have interest expense and debt.

\section{b) Data Analysis Methods}

The data analysis method in this study uses the regression data panel. Data panel regression analysis is a combination of time series and cross section data as one unit regardless of time difference and entity (individual) (Widarjono, 2007). Since the data panel is a combination of time-series and cross-section, the model can be written as follows:

Yit $=\beta_{0}+\beta_{1} X_{i t}+\varepsilon_{i t}$

Description:

$\mathrm{i}=1,2, \ldots, \mathrm{N}$

$\mathrm{t}=1,2, \ldots, \mathrm{T}$

$\mathrm{N}=$ number of observations

$\mathrm{T}=$ the number of times

$\mathrm{N} \times \mathrm{T}=$ number of data panes

So that the model equations can be written in this study that are applied in a model as follows:

$\operatorname{COE}_{1_{i E}}=\beta_{0}+\beta_{1} \operatorname{CSR}_{i t}+\beta_{2} S I Z E_{i t}+\beta_{z} L E V_{i t}+\varepsilon_{i t}$

$\operatorname{COD}_{\mathrm{ix}}=\beta_{0}+\beta_{1} \operatorname{CSR}_{\mathrm{it}}+\beta_{z} S I Z E_{i t}+\beta_{3} L E V_{\mathrm{it}}+\varepsilon_{\text {it }}$

Description:

$\beta 1, \beta 2, \beta 3=$ Variable coefficient

$\mathrm{COE}=$ Cost of equity capital of the company $i$ at the time of $t$

$\mathrm{COD}=$ Cost of corporate debt $\mathrm{i}$ at $\mathrm{t}$ time

$\mathrm{CSR}=$ Corporate Social Responsibility of the company $i$ at the time $t$

SIZE $=$ Company size company $\mathrm{i}$ time $\mathrm{t}$

LEV $=$ Leverage company $i$ time $t$

\section{Results of Research and Discussion}

\subsection{Population and Research Samples}

Based on the criteria that have been set, the number of samples that meet the criteria of 13 companies with 65 observations. The number of samples and observations of research is presented in table 4.1 below: 
Table 2. Population and Research Samples

\begin{tabular}{lcc}
\hline \multicolumn{1}{c}{ Research Sample Company } & Number of companies & Percentage \\
\hline $\begin{array}{l}\text { BUMN companies listed on the Indonesia Stock } \\
\text { Exchange in 2013-2017 }\end{array}$ & 20 & $100 \%$ \\
$\begin{array}{l}\text { Companies that use currencies other than Rupiah } \\
\text { (US Dollar) }\end{array}$ & $(3)$ & $(15 \%)$ \\
$\begin{array}{l}\text { Companies that do not have short-term debt and } \\
\text { long-term debt }\end{array}$ & $(4)$ & $(20 \%)$ \\
$\begin{array}{l}\text { Number of companies that meet the research } \\
\text { sample criteria }\end{array}$ & 13 & $65 \%$ \\
Number of observations (13 x 5 years) & 65 & \multicolumn{1}{c}{ Source : Data processed in 2020 }
\end{tabular}

\subsection{Descriptive Statistics}

The descriptive statistics in this study are presented in Table 4.2 as follows:

Table 3. Descriptive Statistics Research Variables

\begin{tabular}{cccccc}
\hline Variabel & n & Minimum & Maximum & Mean & Std. Deviation \\
\hline COE & 65 & 0.03291 & 1.70926 & 0.42036 & 0.290205439 \\
COD & 65 & 0.00045 & 0.07741 & 0.03000 & 0.016562 \\
CSR & 65 & 0.12088 & 0.97802 & 0.41031 & 0.200175852 \\
SIZE & 65 & 27.85398 & 32.95985 & 30.6031 & 1.283698881 \\
LEV & 65 & 0.08687 & 1.02898 & 0.54663 & 0.190400832 \\
\hline \multicolumn{5}{c}{ Source : Data processed in 2020 }
\end{tabular}

Table 4. Total Corporate Social Responsibility Disclosure Index

\begin{tabular}{ccccc}
\hline Category & GRI & Minimum & Maximum & Mean \\
\hline Economy & 9 & 0.222222 & 1.000000 & 0.482906 \\
Enviromental & 34 & 0.000000 & 1.000000 & 0.316742 \\
Labor Practices and Decent work & 16 & 0.187500 & 1.000000 & 0.641827 \\
Human Rights & 12 & 0.000000 & 0.916667 & 0.278846 \\
Society & 11 & 0.000000 & 1.000000 & 0.356643 \\
Product Responsibility & 9 & 0.000000 & 1.000000 & 0.346154 \\
\hline
\end{tabular}

Source : Data processed in 2020

\subsection{Estimated Data Panel Regression Model}

a) Chow Test

Table 5. Chow Test Results

\begin{tabular}{cccc}
\hline Model & n & Prob. Cross-Section Chi-Square & Best Model \\
\hline COE & 65 & 0.0001 & Fixed Effect Model \\
COD & 65 & 0.0000 & Fixed Effect Model \\
\hline \multicolumn{4}{c}{ Source : Data processed in 2020 }
\end{tabular}

b) Hausman Test

Table 6. Hausman Test Results

\begin{tabular}{cccc}
\hline Model & n & Prob. Cross-Section Random & Best Model \\
\hline COE & 65 & 0.4225 & Random Effect Model \\
\hline
\end{tabular}




\begin{tabular}{cccc}
\hline Model & $\mathbf{n}$ & Prob. Cross-Section Random & Best Model \\
\hline COD & 65 & 0.9846 & Random Effect Model \\
\hline \multicolumn{4}{c}{ Source : Data processed in 2020}
\end{tabular}

\section{c) Lagrange Multiplier Test (The Breusch-Pagan LM Test)}

Table 7. Lagrange Multiplier Test (The Breusch-Pagan LM Test) Results

\begin{tabular}{cccc}
\hline Model & n & Prob. Breusch-Pagan & Best Model \\
\hline COE & 65 & 0.0031 & Random Effect Model \\
COD & 65 & 0.0001 & Random Effect Model \\
\hline \multicolumn{4}{c}{ Source : Data processed in 2020 }
\end{tabular}

Based on the test results from the estimated regression model data panel above then select the best model for each model. The best model for regression data panel model COE is random effect model and for data regression panel model COD is random effect model.

\subsection{Classic Assumption Test Results}

\section{a) Normality Test}

Normality test results are summarized in the following Table 4.7:

\begin{tabular}{ccccc} 
& \multicolumn{4}{c}{ Table 8. Normality Test Results } \\
\hline Model & n & P-value & $\boldsymbol{\alpha}$ & Description \\
\hline COE & 65 & 0.054959 & $>5 \%$ & Normal Distributed Data \\
COD & 65 & 0.002045 & $>5 \%$ & Normal Undistributed Data \\
\hline \multicolumn{4}{c}{ Source : Data processed in 2020 }
\end{tabular}

\section{b) Uji Multikolineritas}

The multicollinerity test results are presented in table 4.8 below:

\begin{tabular}{cccc}
\multicolumn{4}{c}{ Table 9. Multicollinerity Test Results } \\
\hline & CSR & SIZE & LEV \\
\hline CSR & 1.000000 & -0.187173 & 0.006560 \\
SIZE & -0.187173 & 1.000000 & 0.119586 \\
LEV & 0.006560 & 0.119586 & 1.000000 \\
\hline \multicolumn{5}{c}{ Source : Data processed in 2020}
\end{tabular}

\section{c) Heterokedastisity Test}

The results of the heterokedastisity test are summarized in the following table 4.9:

Table 10. Heterokedastisity Test Results

\begin{tabular}{cccc}
\hline Model & Prob.Chi-Square & $\begin{array}{c}\text { Criteria Free } \\
\text { Heteroskedastisity }\end{array}$ & Description \\
\hline COE & 0.3393 & $>5 \%$ & Heteroskedasticity Free \\
COD & 0.0814 & $>5 \%$ & Heteroskedasticity Free \\
\hline \multicolumn{4}{c}{ Source : Data processed in 2020}
\end{tabular}




\subsection{Hypothesis Test}

\section{a) Model Significance Test Results (F Test)}

Table 11. Model Significance Test Results (F Test)
\begin{tabular}{cccc} 
Model & P-value & $\boldsymbol{\alpha}$ & Description \\
\hline COE & 0.039870 & $<5 \%$ & Model Fit \\
COD & 0.024123 & $<5 \%$ & Model Fit \\
\hline Source : Data processed in 2020
\end{tabular}

Based on Table 4.10 for coe regression models it is known that the probability value (Fstatistic) is smaller than $\alpha=0.05$ or $5 \%$ with a value of $0.039870<0.05$ this indicates that the model used is fit or appropriate. Meanwhile, for the COD regression model it is known that the probability value (F-statistic) is smaller than p-value $0.05(\alpha=0.05)$ with a value of $0.024123>0.05$ this indicates that the model used is fit or appropriate.

\section{b) Determination Test Results $\left(\mathbf{R}^{2}\right)$}

\begin{tabular}{|c|c|c|}
\hline Model & R-squared & Adjusted R-squared \\
\hline $\mathrm{COE}$ & 0.626527 & 0.583569 \\
\hline COD & 0.325352 & 0.422581 \\
\hline
\end{tabular}

Based on Table 4.11 it can be seen that the Adjusted R-squared value for the COE model is 0.583569. This suggests that CSR disclosures are influenced by COE by $58.35 \%$ and $41.65 \%$ described by other variables not identified in this research model. Furthermore, the Adjusted $\mathrm{R}$-squared value for the COD model is 0.422581 . This suggests that CSR disclosures are influenced by COD by $42.25 \%$ and $57.75 \%$ described by other variables not identified in this study model.

\section{c) Hypothesis Test $\mathbf{t}$ (Statistical Test $\mathbf{t}$ )}

Table 13. Hypothesis Test Results (T Test)

\begin{tabular}{cccccc}
\hline \multirow{2}{*}{ Variabel } & \multirow{2}{*}{ Hypothetical Direction } & \multicolumn{2}{c}{ COE } & \multirow{2}{*}{$\boldsymbol{*}$ Description } \\
\cline { 3 - 5 } & & Coef. & P-value & & \\
\hline CSR & Negative & -0.384134 & 0.0341 & $<5 \%$ & Accepted \\
SIZE & 0.037057 & 0.0370 & $<5 \%$ & \\
LEV & 0.381167 & 0.1015 & $<5 \%$ & \\
CSR & \multirow{2}{*}{ Negative } & -0.012178 & 0.0872 & $<5 \%$ & \multirow{2}{*}{ Rejected } \\
SIZE & 0.062305 & 0.9900 & $<5 \%$ & \\
LEV & 0.017871 & 0.0252 & $<5 \%$ & \\
\hline \multicolumn{5}{c}{ Source : Data processed in 2020} \\
\end{tabular}

\subsection{Discussion}

\section{a) Disclosure of Corporate Social Responsibility and the Cost of Equity}

Based on the results of the first hypothesis test obtained the result that the variable disclosure of corporate social responsibility negatively affects the cost of equity (COE), so the 
first hypothesis is accepted. This means that a company that makes more detailed and extensive corporate social responsibility disclosures will make the company well known to investors so as to make investors interested in investing its capital in the company. Because of the wide level of disclosure, the company is called issuing a small cost of equity. In addition, the background of BUMN companies whose ownership is the Country where investors have a high level of confidence when investing in BUMN companies. It is also based on table 4.2 which shows that the average cost of equity of so-called BUMN companies has an expected return growth of $42 \%$ over the share price can be said to be high, this is based on the average value close to the maximum value. According to (Easton, 2004) companies that have high return growth will make investors more likely to buy shares in the BUMN company. The high investor interest in the company's shares caused the share price to rise. With the increasing share price of the company, this can make the company gain a high profit. In addition, stakeholder theory states that the company is not an entity that only operates for its own benefit, but should benefit its stakeholders. Therefore, the company conducts corporate social responsibility activities, with the activity of corporate social responsibility then the stakeholders that are investors will not expect more to return when the company cares more about other stakeholders namely society, consumers, kayawan. So that the profit is earned, the company is more eager to prosper other stakeholders that will ultimately have an impact on the low cost of equity demanded by investors.

The results of this study are consistent with research conducted by Bhuiyan and Nguyen (2019) and Rinobel and Laksito (2015) which found evidence that corporate social responsibility disclosure negatively affects the cost of equity (COE).

\section{b) Disclosure of Corporate Social Responsibility and the Cost of Debt}

Based on the results of the second hypothesis test obtained the result that the variable disclosure of corporate social responsibility negatively and insignificantly to the cost of debt (COD), so the second hypothesis was rejected. This is shown from table 4.2 where corporate social responsibility disclosure is highest at $97 \%$ meaning corporate social responsibility disclosure has been done widely and in detail but has an interest expense of $2.0 \%$ interest debt whereas the interest expense of the interest debt is reduced by $0.045 \%$ to only make corporate social responsibility disclosure of $31 \%$. This indicates that creditors often do not use the information available in providing loans, especially corporate social responsibility disclosures. In other words, the information provided by management is too much, while the user's absorption of that information is very limited. Another reason is that the creditors, especially banks, do not pay attention to whether the company has provided more information in terms of corporate social responsibility disclosure to creditors or not, even sometimes the financial statements provided by the company tend to be ignored.

The bank will pay more attention to the fulfillment of the company's requirements at $5 \mathrm{C}$, namely character, capability, collateral, condition of economy, and capital. The 5C requirement that must be met, can be one of the considerations for banks in giving loan decisions to companies. Based on the data in table 4.2 means that the lender does not see the size or small confidence of the public, consumers, employees, media and government owned by the company, such as a state-owned enterprise whose background is the State, does not mean it can be a positive assessment by the lender in terms of loan repayment, but a company that has a good credit history or loan, will certainly give a positive assessment also for the creditors. So creditors trust the company's credibility more in terms of loan repayments. The results of this study also do not support the stakeholder theory that corporate social 
responsibility disclosure can lower loan repayments in the form of interest charged by creditors.

The results of this study contradict the results of research conducted by Bhuiyan and Nguyen (2019) and Goss and Roberts (2011) which found evidence that corporate social responsibility disclosure negatively affects the cost of debt (COD). But the results of this study support research conducted by Arianti (2019) the results show that corporate social responsibility disclosure has no effect on the cost of debt, where creditors often do not use the information available in lending such as corporate social responsibility disclosure. Creditors rate the company's track record in borrowing a debt, whether rated good or bad. This will give creditors more assessment of the company than just looking at corporate social responsibility disclosures that are not necessarily positive value to the creditor's valuation.

\section{Summations, Implications, Limitations, And Suggestions}

\subsection{Conclusion}

This study provides the conclusion that corporate social responsibility disclosure has an influence on the cost of equity. Meanwhile, corporate social responsibility disclosure has no effect on the cost of debt.

\subsection{Implications of Research Results}

The theoretical implications of this study explain the effect of corporate social responsibility disclosure on the cost of equity and cost of debt through stakeholder theory. Stakeholder theory in this study can provide a basis for understanding that stakeholders are able to encourage companies to disclose corporate social responsibility. Disclosure made by the company is not only directed at its stakeholders but to all interested parties in accordance with the stakeholder theory, the stakeholders in question are the owners of the company, investors, governments, employees, consumers, environmental activists and the media. The Company will certainly be well known by the stakeholders who are many in accordance with the scope of the company. With the company's known by as well as good communication with company owners, investors, governments, employees, consumers, environmental activists and media expected the company's business activities to run in line with expectations.

While the practical implications of this research for companies, the results of this study are expected to give consideration and contribution to the company as an evaluation to further raise awareness of the importance of making corporate social responsibility disclosure. For the government, the results of this research are expected to provide consideration or input in policymaking related to corporate social responsibility and can motivate companies in conducting corporate social responsibility disclosure activities. For further research can be used as a reference for further research on corporate social responsibility disclosure to the cost of capital. The limitations in this study have problems in the normality test on dependent variables cost of debt, so this study has not met the classic assumption test. And the result of the determination coefficient in this study was only $42.25 \%$ which means that the independent variables in this study have not been able to explain the dependent variable cost of debt. The advice in this study is to hope that all data is free from the classic assumption problem by having the right proxy for each variable. Further research should add other variables as cost of 
debt proxies, such as corporate governance variables, tax avoidance, intellectual capital disclosure and others.

\section{References}

[1] Arianti, B. F. (2019). Pengaruh Pengungkapan Sukarela, Penghindaran Pajak dan Corporate Governance Terhadap Biaya Hutang. Journal of Economic and Management Scienties, 2(1), 14-29.

[2] Ariyani, M., \& Nugrahanti, Y. W. (2013). Pengaruh Pengungkapan Corporate Social Responsibility Terhadap Cost Of Equity. Telaah Bisnis, 14(1), 1-26.

[3] Bhuiyan, M. B. U., \& Nguyen, T. H. N. (2019). Impact of CSR on cost of debt and cost of capital Australian evidence. Journal Social Responsibility, 15(3), 1-12.

[4] Botosan, C. A. (1997). Disclosure level and the cost of equity capital. The Accounting Review, 72(3), 323-349.

[5] Dhaliwal, D. S., Li, O. Z., Tsang, A., \& Yang, Y. G. (2011). Voluntary Nonfinancial Disclosure and the Cost of Equity Capital The Initiation of Corporate Social Responsibility Reporting. 86(1), 59-100.

[6] Easton, P. D. (2004). Expected Implied on Equity Capital Estimating of Return on Equity Capital. Journal American Accounting Association, 79(1), 73-95.

[7] Elkington, J. (1997). Cannibals with forks The Triple Bottom Line of Twentieth Century Business. United Kingdom: Capstone.

[8] Fabozzi, F. J. (2007). Bond markets, Analysis and Strategies (6th ed.). New Jersey: Prentice Hall.

[9] Francis, J. R., \& Pereira, R. (2005). Disclosure Incentives and Effects on Cost of Capital around the World. The Accounting Review, 80(4), 1125-1162.

[10] Freeman, R. E. (1984). Srtategic Management A Stakeholder Approach. London: Pitman Publishing Ins.

[11] Goss, A., \& Roberts, G. S. (2011). The impact of corporate social responsibility on the cost of bank loans. Journal of Banking and Finance, 35(7), 1794-1810.

[12] Kasmir. (2009). Analisis Laporan Keuangan. Jakarta: Rajawali pers.

[13] Lako, A. (2011). Dekonstruksi CSR dan Reformasi paradigma Bisnis dan Akuntansi. Jakarta: Erlangga.

[14] Lawrence, A. T., \& Weber, J. (2008). Business and Society Stakeholders, Ethics and Public Policy (12th ed.). USA: McGraw-Hill/Irwin a business unit of The McGrawHill Companies Inc.

[15] Mardiyah, A. A. (2002). Pengaruh Informasi Asimetri dan Disclosure terhadap Cost of Capital. Jurnal Riset Akuntansi Indonesia, 5(2), 229-256.

[16] Rinobel, B., \& Laksito, H. (2015). Pengaruh pengungkapan corporate social responsibility ( CSR ), ukuran perusahaan, financial leverage dan manajemen laba terhadap cost of equity perusahaan. Jurnal Akuntansi Universitas Diponegoro, 4(2), 19.

[17] Ross, S. A., Westerfield, R. W., \& Jaffe, J. F. (1998). corporate finance (10th ed.). Americas, New York: McGraw-Hill/Irwin a business unit of The McGraw-Hill Companies Inc.

[18] Trisnawati, R., \& Setiawati, E. (2016). Pengaruh pengungkapan corporate social responsibility terhadap cost of equity capital. The 4 Th Univesity Research Coloquium, 2(2), 132-144. 
[19] Widarjono, A. (2007). Ekonometrika Teori dan Aplikasi untuk Ekonomi dan Bisnis (2nd ed.). Yogyakarta: Ekonisia FE Universitas Islam Indonesia. 